\title{
Lactic Acid Production from 1,2-Propanediol by Jar Culture and Resting Cells of Arthrobacter oxydans
}

\author{
Osami YaGI and Yasuji MinodA* \\ The National Institute for Environmental Studies, Tsukuba-gun, Ibaraki \\ * Department of Agricultural Chemistry, Faculty of \\ Agriculture, The University of Tokyo, Tokyo
}

Received September 6, 1978

\begin{abstract}
Arthrobacter oxydans (PG21-1) which was isolated from soil preferably assimilated 1,2propanediol and produced remarkable amount of lactic acid. Cultural conditions for lactic acid production from 1,2-propanediol were studied using a 15 liter jar fermentor. Optimum $\mathrm{pH}$ and urea concentration for the production of lactic acid were 8.0 and $0.3 \%$, respectively. Under these conditions, the yield of lactic acid was $17.8 \mathrm{~g} /$ liter in 7 day cultivation. About $70 \%$ of the utilized 1,2-propanediol was converted to lactic acid. The production of lactic acid by resting cells was also investigated. Resting cells of Arthrobacter oxydans showed a high activity to produce lactic acid at alkaline $\mathrm{pH}$ and the amount of the acid reached to $10.2 \mathrm{~g}$ /liter in $12 \mathrm{hr}$ incubation. The accumulation of lactic acid at alkaline side was considered to due to the strong suppression of the degradation of lactic acid.
\end{abstract}

In the previous paper, ${ }^{11}$ it was reported that Arthrobacter oxydans, which was isolated from soil, produced lactic acid from 1,2-propanediol and that $\mathrm{pH}$ and urea were the effective factors to promote the accumulation of lactic acid.

Lactic acid is used in various fields, such as food, drink, leather and textile industries. Moreover, lactic acid is thought to be useful as a monomer of synthetic substances because of having two functional groups in the molecule. At present, lactic acid is made by chemical synthesis or bacterial fermentation. However, the price is fairly high. 1,2-Propanediol is one of the petrochemicals and a relatively cheap and safe material. Therefore, lactic acid production from 1,2-propanediol by microorganisms is of great advantage.

In this paper, optimal conditions of lactic acid production from 1,2-propanediol using a jar fermentor and the accumulation of lactic acid by resting cells were investigated.

\section{MATERIALS AND METHODS}

Microorganism. Arthrobacter oxydans PG21-1, which was isolated from soil by screening procedures as described in the previous paper ${ }^{1)}$ was used throughout this investigation.
Medium. The composition of basal medium was as follows: 1,2-propanediol $30.0 \mathrm{~g}$, urea $3.0 \mathrm{~g}, \mathrm{~K}_{2} \mathrm{HPO}_{4}$ $1.0 \mathrm{~g}, \mathrm{MgSO}_{4} \cdot 7 \mathrm{H}_{2} \mathrm{O} 0.5 \mathrm{~g}, \mathrm{KCl} 0.5 \mathrm{~g}, \mathrm{FeSO}_{4} \cdot 7 \mathrm{H}_{2} \mathrm{O}$ $0.01 \mathrm{~g}$, yeast extract $0.5 \mathrm{~g}$ and tap water to make 1 liter.

Cultivation. Inoculum was prepared as follows: A loopful of cells grown on 1,2-propanediol agar slant for 2 days was inoculated to $50 \mathrm{ml}$ of basal medium in a $500-\mathrm{ml}$ reciprocal flask and incubated for $36 \mathrm{hr}$ at $30^{\circ} \mathrm{C}$. Main cultivation was carried out in a 15 -liter jar fermentor containing 8 liters of liquid medium with an agitation speed of $500 \mathrm{rpm}$ and aeration of 8 liters per min at $30^{\circ} \mathrm{C}$. pH was continuously controlled with $5 \mathrm{~N} \mathrm{NaOH}$ and $4 \mathrm{~N} \mathrm{HCl}$.

Preparation of resting cells. Cells grown at $30^{\circ} \mathrm{C}$ for $36 \mathrm{hr}$ in basal medium were harvested by centrifugation at $10,000 \times g$ for $10 \mathrm{~min}$ and washed two times with $1 / 15 \mathrm{M}$ potassium-sodium phosphate buffer $(\mathrm{pH}$ 7.0). The cells thus obtained were suspended in various kinds of buffer and used as resting cell suspension.

Lactic acid production by resting cells. The activity of resting cells for lactic acid production was assayed by measuring the amount of the acid produced in the reaction mixture containing $5 \mathrm{ml}$ of resting cell suspension, $40 \mathrm{ml}$ of $0.5 \mathrm{M}$ buffer and $5 \mathrm{ml}$ of 1,2-propanediol after incubation for definite time at $30^{\circ} \mathrm{C}$ on a shaker.

Oxygen uptake experiment. Warburg flask containing $0.1 \mathrm{ml}$ of cell suspension ( $2 \mathrm{mg}$ dry cells), $0.3 \mathrm{ml}$ of substrate solution, $1.6 \mathrm{ml} 1 / 15 \mathrm{~m}$ various buffer and $0.3 \mathrm{ml}$ of $20 \% \mathrm{KOH}$ solution (in center well) in a total volume $2.3 \mathrm{ml}$ were incubated at $30^{\circ} \mathrm{C}$ with shaking 
and oxygen uptake of resting cells was measured manometrically.

Determination of cell growth, 1,2-propanediol and lactic acid. Cell growth was determined by the optical density at $660 \mathrm{~nm}$. 1,2-Propanediol was measured by gas chromatography using a Hitachi Gaschromatograph K-53 with flame ionization detector. Conditions of gas chromatography was as follows: Stainless steel column ( $1 \mathrm{~m}$ long, $3 \mathrm{~mm}$ i.d.) was packed with Chromosorb 101. Column and injection temperature were $170^{\circ} \mathrm{C}$ and $210^{\circ} \mathrm{C}$ respectively. Carrier gas was $\mathrm{N}_{2}$ and flame gas was a mixture of $\mathrm{H}_{2}$ and air. Lactic acid was determined with the same way as mentioned in the previous paper. ${ }^{1}$ )

1,2-Propanediol. 1,2-Propanediol was obtained from Junsei Chemical Co., Ltd. and used without further purification.

\section{RESULTS}

\section{Effect of $p H$ on lactic acid production}

In the previous paper, ${ }^{1)}$ it was found that initial $\mathrm{pH}$ was one of the most important factors on lactic acid production by a reciprocal flask. This time, effect of $\mathrm{pH}$ was studied using a jar fermentor with $\mathrm{pH}$ control apparatus. $\mathrm{pH}$ of the culture medium was kept at various levels by adding appropriate amount of $5 \mathrm{~N} \mathrm{NaOH}$ and $4 \mathrm{~N} \mathrm{HCl}$. In order to clarify the cultural characteristics, accumulation of lactic acid, cell growth and consumption of 1,2-propanediol were investigated throughout the cultivation.

Figure 1 shows the time course of lactic acid production using a 15 -liter jar fermentor. $\mathrm{pH}$ was not controlled. Celís grew exponentially for $60 \mathrm{hr}$ after a short lag and the maximum cell concentration reached to about $4.5 \mathrm{~g} / \mathrm{liter}$. The accumulation of lactic acid increased in proportion to the cell growth and continued after the cell growth stopped. The maximum amount of lactic acid was about $5.1 \mathrm{~g} /$ liter. $\mathrm{pH}$ of the culture broth rose to 9.0 initially but $\mathrm{pH}$ was lowering after $30 \mathrm{hr}$. These results were almost the same as those of the cultivation using a $500 \mathrm{ml}$ reciprocal flask reported in the previous paper. ${ }^{13}$

Figure 2 shows the time course of lactic acid production when $\mathrm{pH}$ was adjusted to 7.0. The

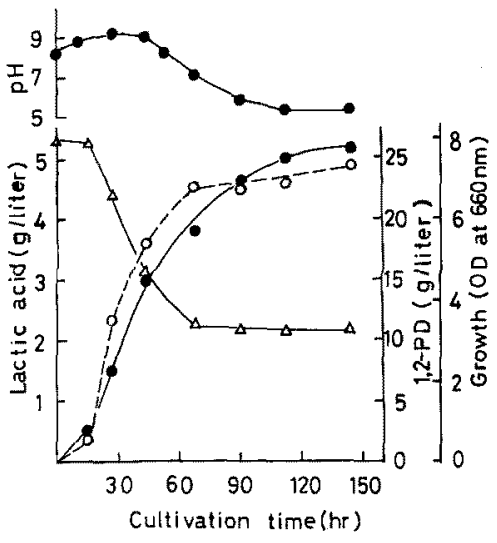

Fig. 1. Time Course of Lactic Acid Production. -- lactic acid; $\bigcirc--O$, growth; $\triangle-\Delta, 1,2-\mathrm{PD}$.

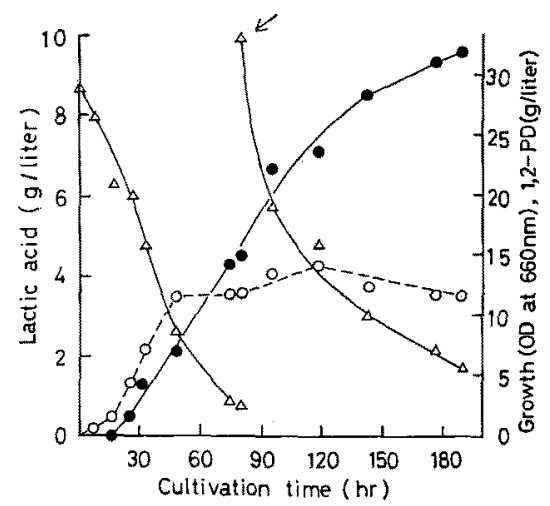

FrG. 2. Lactic Acid Production by Jar Fermentor, Cultivation was carried out at $\mathrm{pH} 7.0$.

-- lactic acid; $0-\mathrm{O}$, growth; $\triangle-\Delta, 1,2-\mathrm{PD}$.

maximum cell concentration was obtained after $45 \mathrm{hr}$ cultivation. The growth rate and final cell concentration were higher than those of the cultivation of which $\mathrm{pH}$ was not controlled. But the accumulation of lactic acid was almost the same. Most of 1,2-propanediol was consumed after $85 \mathrm{hr}$ cultivation, then $240 \mathrm{~g}$ of 1,2-propanediol was added at that time (shown by arrow) and the cultivation was continued. As shown in Fig. 2, the addition of 1,2-propanediol caused the increase in lactic acid accumulation but the cells were scarcely increased.

Figure 3 shows the time course of lactic acid production at pH 8.0. The cell growth became maximum in $70 \mathrm{hr}$ but lactic acid production increased linearly until 1,2-propanediol 


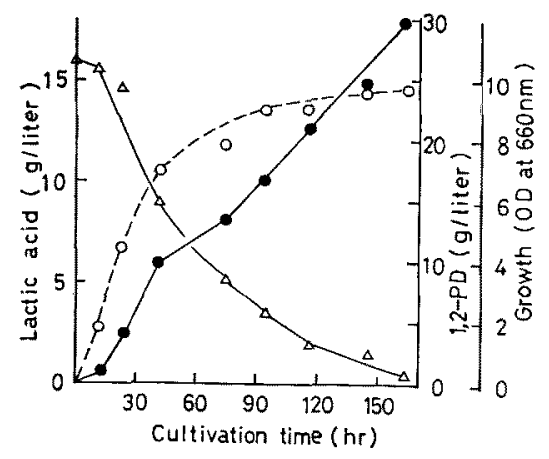

Fig. 3. Lactic Acid Production by Jar Fermentor. Cultivation was carried out at $\mathrm{pH}$ 8.0.

$\bullet-\bullet$ lactic acid; $\bigcirc---O$, growth; $\triangle-\Delta$, 1,2-PD.

was consumed completely.

\section{Effect of concentration of urea on lactic acid production}

In general, accumulation of organic acid is closely related to concentration of nitrogen source. $^{2)}$ In this fermentation, urea as nitrogen source was suitable for lactic acid production and cell growth. Therefore, effect of concentration of urea on lactic acid production using a 15 liter jar fermentor was studied. $\mathrm{pH}$ of culture broth was controlled at 8.0 and the concentration of 1,2-propanediol was about $3 \%$ in all cases.

Figure 4 shows effect of urea concentration on lactic acid production. Under the condition of $0.03 \%$ urea, the cell growth and the

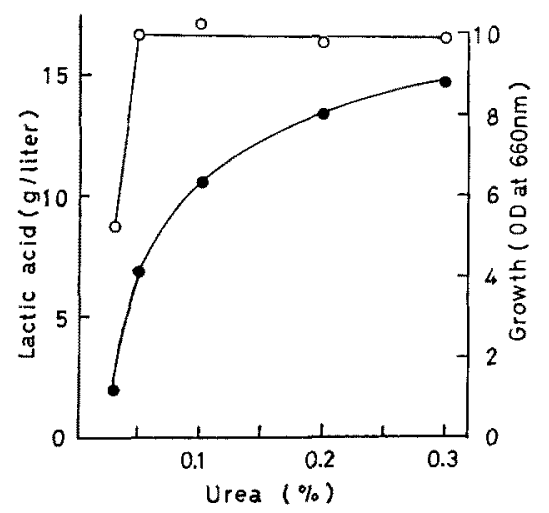

Frg. 4. Effect of Urea Concentration on Lactic Acid Production.

Cultivation was carried out for 6 days using a 15 liter jar fermentor. $\mathrm{pH}$ of culture medium was kept at 8.0.

$\longrightarrow$ - lactic acid; $0-0$, growth. accumulation of lactic acid were both depressed. However, in the case of $0.05 \%$ urea, the cell growth was abundant but the production of lactic acid was low. The best concentration of urea was $0.3 \%$.

\section{Lactic acid production by resting cells}

Effect of $\mathrm{pH}$ on lactic acid production by resting cells grown on 1,2-propanediol medium is shown in Fig. 5. Lactic acid was most abundantly accumulated at pH $8.0 \mathrm{in} 12 \mathrm{hr}$ incubation and the amount of lactic acid reached to $10.2 \mathrm{~g} /$ liter. However, in $48 \mathrm{hr}$ culture the accumulation of lactic acid was maximum at initial $\mathrm{pH}$ of 9.5 and at that time the $\mathrm{pH}$ of culture was decreased to 8.0 . In the alkaline side, the accumulation of lactic acid markedly increased but in the acidic side, the accumulation of lactic acid remarkably decreased.

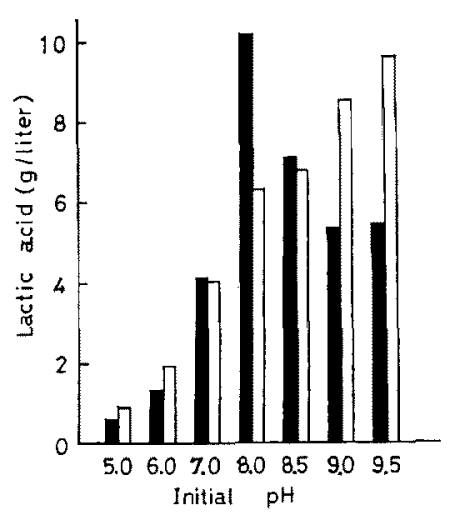

FIG. 5. Lactic Acid Production by Resting Cells. Concentration of resting cells in the reaction mixture was $9.0 \mathrm{~g} /$ liter. $\mathrm{pH} 5.0,6.0,7.0$, phosphate buffer; $\mathrm{pH} 8.0,8.5,9.0,9.5$, Tris buffer. Incubation time: $\square, 12 \mathrm{hr} ; \square, 48 \mathrm{hr}$.

Table I shows the lactic acid production by resting cells cultivated with various carbon sources. 1,2-Propanediol was the best carbon source for the preparation of resting cells. Resting cells grown on bouillon medium had a relatively high activity to produce lactic acid.

\section{$\mathrm{O}_{2}$ Uptake for 1,2-propanediol and lactic acid} by resting cells

In order to elucidate effect of $\mathrm{pH}$ on lactic acid production, $\mathrm{O}_{2}$ uptake for 1,2-propanediol and lactic acid by resting cells was studied. 
Table I. Lactic Acid Production by Resting

Cells Grown on Various Carbon Sources

Resting cells grown in basal medium containing $1 \%$ of each carbon source instead of 1,2-propanediol were used. Incubation was carried out using $0.5 \mathrm{M}$ phos-

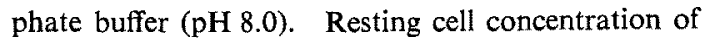
the reaction mixture was $4.8 \mathrm{~g} /$ liter. 1,2-Propanediol concentration was $3 \%$.

\begin{tabular}{llc} 
Carbon sources & \multicolumn{2}{c}{$\begin{array}{c}\text { Lactic acid (g/liter) } \\
\text { incubation time } \\
6 \mathrm{hr}\end{array}$} \\
\hline Meat extract & 0.25 & 1.68 \\
Glucose & 0.47 & 0.93 \\
Mannose & 0.23 & 0.36 \\
Sucrose & 0.10 & 0.03 \\
Sorbitol & 0.29 & 0.50 \\
1,2-Propanediol & 1.20 & 3.50 \\
\hline
\end{tabular}

Figure 6 shows effects of $\mathrm{pH}$ on $\mathrm{O}_{2}$ uptake for 1,2-propanediol. The maximum $\mathrm{O}_{2}$ uptake was found at $\mathrm{pH} 7.0$ in $2.25 \%$ of 1,2 -propanediol. When $0.75 \%$ of 1,2-propanediol was used, $\mathrm{O}_{2}$ uptake was almost the same in the range of $\mathrm{pH} 6.0$ to 9.0 , and $\mathrm{O}_{2}$ uptake in $2.25 \%$ of 1,2-propanediol was higher than in $0.75 \%$.

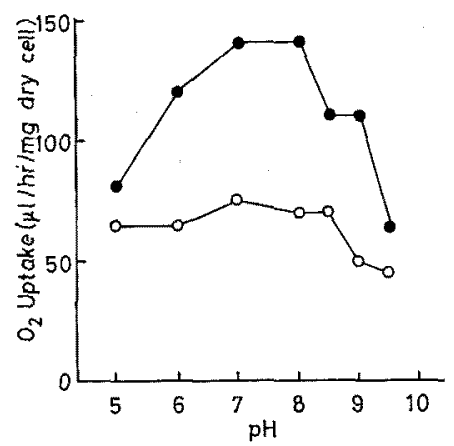

Fig. 6. Effect of $\mathrm{pH}$ on Oxygen Uptake for 1,2Propanediol.

pH 5.0, 6.0, 7.0, phosphate buffer; pH 8.0, 8.5, 9.0, Tris buffer; $\mathrm{pH} 9.5$, borate buffer. Concentration of 1,2-PD: - $2.25 \% ; 0-0,0.75 \%$.

Figure 7 shows effect of $\mathrm{pH}$ on $\mathrm{O}_{2}$ uptake for lactic acid. $\mathrm{O}_{2}$ uptake was much affected by the concentration of lactic acid and pH. In the high concentration of lactic acid, the optimum $\mathrm{pH}$ for $\mathrm{O}_{2}$ uptake was 7.0 but in the low concentration, the optimum $\mathrm{pH}$ for $\mathrm{O}_{2}$ uptake was 5.0 .

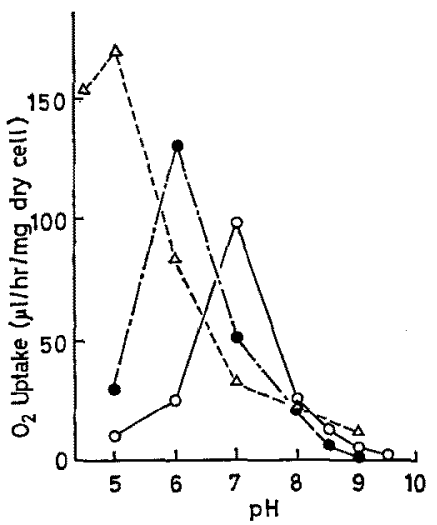

FIG. 7. Effect of $p H$ on Oxygen Uptake for Lactic Acid.

Concentration of Na-lactate: $\mathrm{O}-\mathrm{O}, 2.25 \%$; $0.75 \% ; \triangle--\triangle, 0.13 \%$.

\section{DISCUSSION}

Arthrobacter oxydans which was isolated from soil preferably assimilated 1,2-propanediol and produced remarkable amount of lactic acid. As shown in Figs. 2 and 3, high growth was observed but lactic acid was not much accumulated at neutral $\mathrm{pH}$ while at alkaline side the rate of cell growth became slow but lactic acid was accumulated abundantly. The most favourable $\mathrm{pH}$ for lactic acid production was 8.0. It is interesting that an organic acid is produced in a large quantity in alkaline condition.

Urea was the most favourable nitrogen source for lactic acid production. The optimum urea concentration was $0.3 \%$. Usually, low concentration of nitrogen source is favorable for the production of organic acid. But in this cultivation, much more amount of urea than that required for the sufficient cell growth was necessary for lactic acid production. The reason was not clarified.

Under the most favorable conditions for lactic acid production using a 15 liter jar fermentor, the amount of lactic acid reached to $17.8 \mathrm{~g} /$ liter in 7 day cultivation and the consumed 1,2-propanediol was $26.0 \mathrm{~g} /$ liter. Therefore the yield of lactic acid from 1,2-propanediol was about $70 \%$.

Lactic acid was produced associating with 
the cell growth in early phase and the acid production continued after the stopping of cell growth. If the cultivation is carried out under the favorable conditions of the cell growth in early phase and then under the favorable conditions of lactic acid production in later phase, the production rate of lactic acid is expected to be extremely high.

As shown in Fig. 5, resting cells of Arthrobacter oxydans possessed a high ability of lactic acid production and the production by resting cells was much affected by pH similarly to that by growing cells. Though buffer action of $0.5 \mathrm{M}$ buffer was not sufficient to keep the $\mathrm{pH}$ of the reaction mixture constant, the optimum $\mathrm{pH}$ for lactic acid production was 8.0 and the amount of lactic acid was $10.2 \mathrm{~g} /$ liter in $12 \mathrm{hr}$ incubation. The production rate was 0.095 $\mathrm{g} / \mathrm{hr} / \mathrm{g}$ dry cell. This rate was about 2 times higher than that of growing cells. However, the decomposition of lactic acid was observed in a long period of incubation. Since the activity of lactic acid production by resting cells is stable for a long time and the degradation of lactic acid is inhibited completely, the use of resting cells is very advantageous. ${ }^{3}$ '

To clarify the reason of lactic acid accumulation at the alkaline side, $\mathrm{O}_{2}$ uptake for 1,2propanediol and lactic acid was studied. $\mathrm{O}_{2}$ uptake for 1,2-propanediol was not much affected by $\mathrm{pH}$ and the concentration. However, $\mathrm{O}_{2}$ uptake for lactic acid extremely decreased at higher $\mathrm{pH}$ than 8 in any concentrations. The accumulation of lactic acid at alkaline side was considered to be owing to the strong supression of the degradation of lactic acid. The optimum $\mathrm{pH}$ for $\mathrm{O}_{2}$ uptake on lactic acid changed with the concentration of lactic acid. The reason is not obvious.

\section{REFERENCES}

1) O. Yagi and K. Yamada, Agric. Biol. Chem., 33, 1587 (1969).

2) T. Kodama, U. Kotera and K. Yamada, J. Ferment. Technol., 49, 93 (1971).

3) R. Uchio and I. Shïo, Agric. Biol. Chem., 36, 1169 (1972). 